\title{
THE SECURITIZATION OF ASYLUM SEEKERS IN CANADIAN POLITICAL DISCOURSE
}

\author{
By \\ Rajwant Deo, BA, Wilfrid Laurier University, 2013 \\ A Major Research Paper \\ presented to Ryerson University \\ In partial fulfillment of the requirements for the degree of \\ Master of Arts \\ in the Program of \\ Immigration and Settlement Studies
}

Toronto, Ontario, Canada, 2014

(C) Rajwant Deo, 2014 


\section{Author's Declaration}

I hereby declare that I am the sole author of this Major Research Paper. This is a true copy of the MRP, including any required final revisions, as accepted by my examiners.

I authorize Ryerson University to lend this MRP to other institutions or individuals for the purpose of scholarly research

I further authorize Ryerson University to reproduce this MRP by photocopying or by other means, in total or in part, at the request of other institutions or individuals for the purpose of scholarly research.

I understand that my MRP may be made electronically available to the public. 


\title{
THE SECURITIZATION OF ASYLUM SEEKERS IN CANADIAN POLITICAL DISCOURSE
}

\author{
Rajwant Deo \\ Master of Arts, 2014 \\ Immigration and Settlement Studies \\ Ryerson University
}

\begin{abstract}
This study examines the representation of asylum seekers in Canadian political discourse published between 2009 and 2012. During this time period, Tamil asylum seekers arrived in Vancouver on the Ocean Lady and MV Sun Sea. Also in 2010 and in 2012 Bill C-11 and Bill C31 were introduced, which resulted in harsh changes to Canada's asylum system. This study used securitization theory to understand how asylum seekers were presented as threats and the exceptional measures which were implemented to deal with them. It was found that asylum seekers were depicted in a very negative manner where they were accused of abusing the system, burdening the economy, and conspiring with migrant smugglers. This justified number of policies including the designated country of origin policy, mandatory detention for irregular arrivals, and cuts to refugee health care. These new policies were found to be inconsistent with the Canadian Charter of Rights and Freedoms.
\end{abstract}

Key Words: Asylum Seeker, Political Discourse, Securitization Theory 


\section{Acknowledgements:}

I would like to thank my wonderful supervisor, Dr. Idil Atak, for her continual support, patience and guidance. I also want to thank Dr. Harald Bauder for agreeing to become my second reader and for his feedback.

Lastly, I would like to acknowledge my family for their continuous support. 


\section{Table of Contents}

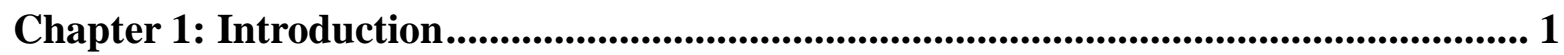

Tamil Asylum Seekers and Their Arrival to Canada .............................................. 1

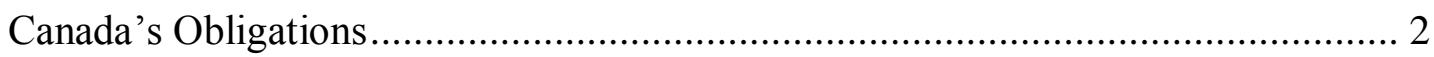

Canada's Asylum System .............................................................................. 3

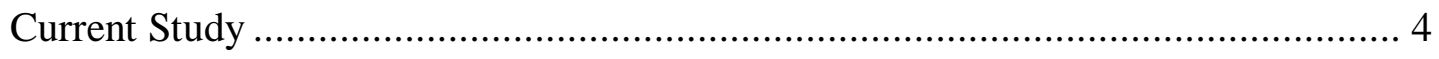

Chapter 2: Literature Review.................................................................................... 7

Representation of Asylum Seekers in political discourse: Recurrent Themes ....................... 8

Chapter 3: Theoretical Framework ............................................................................... 17

Chapter 4: Methodology …................................................................................................................... 21

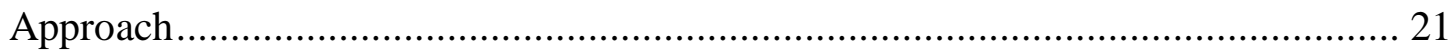

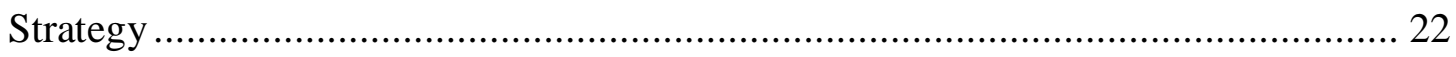

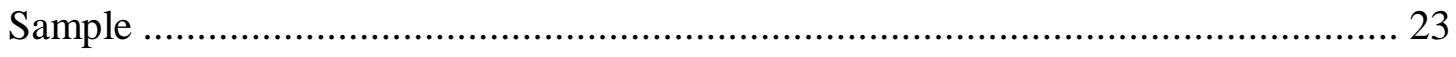

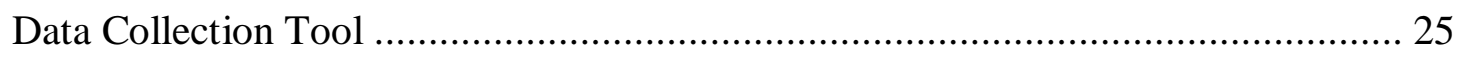

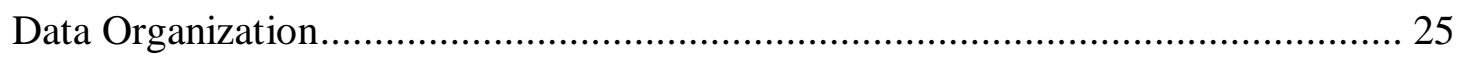

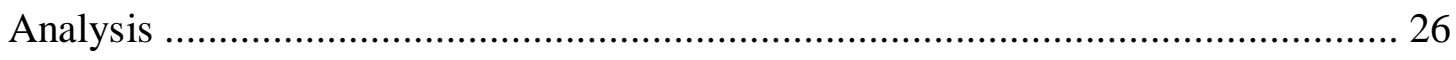

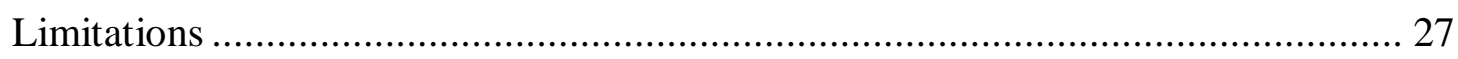

Chapter 5: Results Part I - Representation of Asylum Seekers ............................................ 28

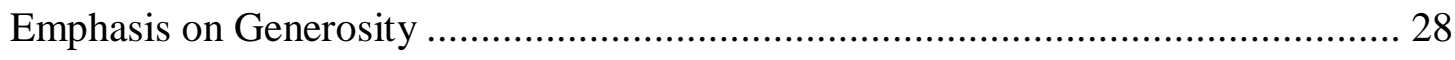

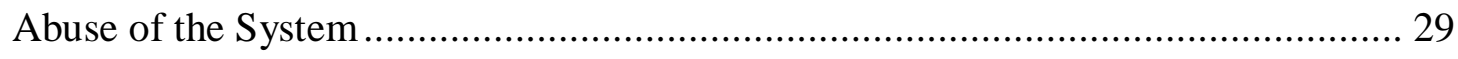

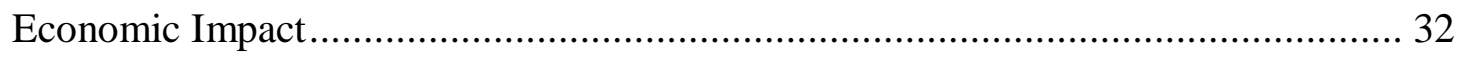

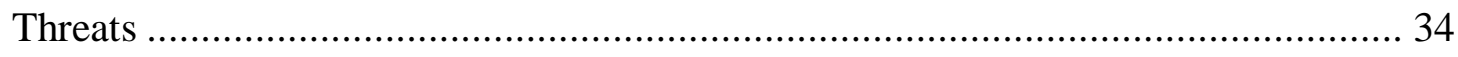

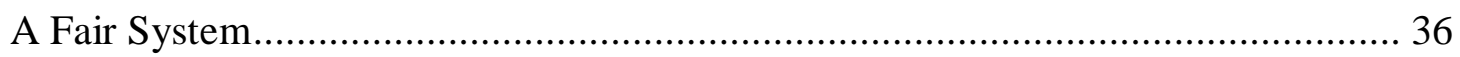

Chapter 6: Results Part II-Impact of Political Discourse on Canada's Asylum System .39

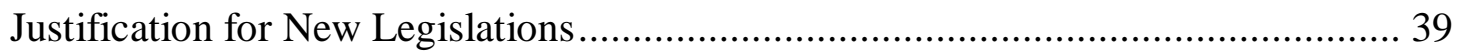


Designated Country of Origin ................................................................ 41

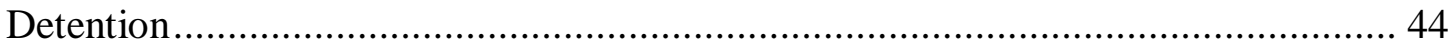

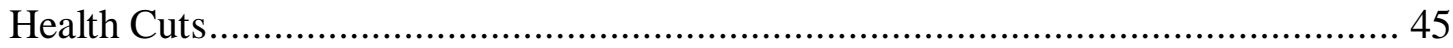

Chapter 7: Conclusion ............................................................................................................. 47

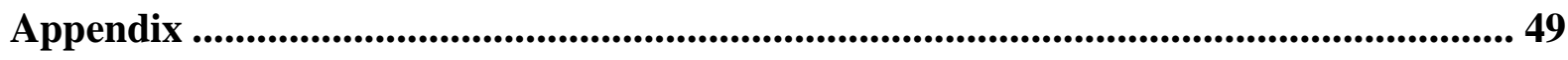

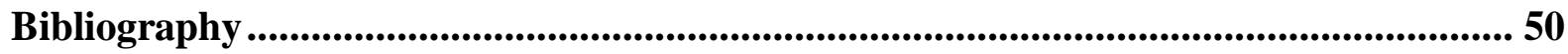




\section{CHAPTER 1: INTRODUCTION}

$\underline{\text { Tamil Asylum Seekers and Their Arrival to Canada }}$

On October 17, 2009, 76 Tamil asylum seekers arrived by boat on the Ocean Lady to Canada, followed by 492 on August 12, 2010, on the MV Sun Sea. At the time of their arrival, the Sri Lankan regime had interned 3,000,000 civilians into barbed wire camps. This was due to the continuous violence between the Sri Lankan state and the Liberation Tigers of Tamil Eelam (LTTE). The individuals who arrived in Canada were escaping this persecution (Canadian Tamil Congress, 2010).

The LTTE have been labeled a Tamil terrorist group involved in an ongoing ethnic conflict against the Singhalese in Sri Lanka (Samaranayake, 2007). The Tamil population makes up a minority in Sri Lanka and have been fighting to separate from the Singhalese population in order create their own independent socialist state. There have been several violent encounters between the LTTE and the Singhalese such as massacres, assassinations and suicide bombings (Samaranayake, 2007). In 2009, the Sri Lankan government decided to put an end to the 25 year long conflict and liberate Sri Lanka from the LTTE (Weaver \& Chamberlin, 2009). At this time, accusations emerged of the Sri Lankan government committing war crimes and executions of Tamils in Sri Lanka. This resulted in the arrival of Tamil asylum seekers on Canada's shores (Canadian Tamil Congress, 2010).

Once they arrived to Canada, Tamil asylum seekers were treated harshly and placed into detention centres (Canadian Tamil Congress, 2011). This resulted in men, women and children spending months in detention centres. In most cases, asylum seekers are not detained, and if they are, it is usually for a few days or weeks (Nakache, 2011). However, the government took a very 
aggressive approach with those who arrived on the Ocean Lady and the MV Sun Sea. It demanded more proof of identity than usual and scrutinized those who were deemed to have weak stories or claims (Canadian Tamil Congress, 2011). These procedure place asylum seekers at greater risk of developing mental health issues and decrease their ability to advance in their asylum claims (Nakache, 2011).

The government justified these harsh acts by claiming human smugglers were involved in the arrival of Tamil asylum seekers, and potential terrorists from the LTTE could be among them. A majority of these individuals were deemed as legitimate refugee claimants, given parole and eventually left the detention centres (Perrin, 2011). Out of the 76 asylum seekers who arrived on the Ocean Lady, all were released under terms and conditions of the Immigration and Refugee Board (IRB) and four were eventually arrested for migrant smuggling offences. As of now, out of the 492 who arrived on the MV Sun Sea, 19 were given deportation orders and 6 had their claims rejected (Perrin, 2011).

\section{Canada's Obligations}

In 1951, Canada became a signatory to the United Nations Convention Relating to the Status of Refugees (Refugee Convention, 1951). By signing this treaty, the Canadian government agreed to abide by specific legal obligations and rights for refugees and asylum seekers. According to the Refugee Convention, a refugee is a person "owing to well-founded fear of being persecuted for reasons of race, religion, nationality, membership of a particular social group or political opinion, is outside the country of his [sic] nationality and is unwilling or unable to avail himself [sic] of the protection of that country, or return to this country for fear of persecution" (Refugee Convention, 1951, art.1). An asylum seeker is defined as a person who is 
seeking protection and their refugee status is yet to be determined (Rowe \& O’Brien, 2013).

"The Refugee Convention discourages the criminalization of asylum seekers and states shall not impose penalties on account of their illegal entry or presence on refugees" (Refugee Convention, 1951, art.31).

\section{Canada's Asylum System}

In order to apply as a refugee, asylum seekers must follow the rules outlined in the Immigration and Refugee Protection Act (IRPA) (S.C. 2011, s.27). A claim for refugee protection can be made in or outside of Canada (S.C. 2011, s.27). If a claim for refugee protection is made outside of Canada, it must be made by completing an application for a visa as a Convention Refugee or a person in similar circumstances (S.C. 2011, s.27). A claim made inside Canada by a person must be made to an officer. It may not be made by the person who is subject to a removal order. A claim inside Canada by a person not at a port of entry must provide the officer with documents and information; this includes respect for the basis of the claim (S.C. 2011, s.27). In order to apply as a Convention Refugee, someone must have a well-founded fear of being persecuted because of their race, religion, political opinion, nationality, or membership to a specific group (S.C. 2011, s.27). A person in need of protection is someone who faces the following dangers if they returned to their home country or country where they normally live: a danger of torture a risk to their life, or a risk of cruel and unusual treatment or punishment (S.C. 2011, s.27).

According to the Immigration and Refugee Protection Act, asylum seekers on the Ocean Lady and MV Sun Sea did apply for refugee status correctly (S.C. 2011, s.27). They claimed asylum at the port of entry; therefore, their claims were legitimate. They should have been 
processed in accordance to the asylum system and should not have been exposed to the harsh treatment they encountered. However, this was not the case because of the depiction of these asylum seekers in the narratives presented by the Ministry of Citizenship and Immigration and the Ministry of Public Safety. The Canadian government continually labelled those on the boats as security threats or as terrorists who are a part of the LTTE (No One is Illegal, 2010). They were also claimed to be health threats to the Canadian population, potentially carrying Tuberculosis (Shakir, 2010). The government referred to them as queue jumpers who cheated Canada's asylum system (No One is Illegal, 2010).

Some of the above claims made by the government were found to be false (Shakir, 2010). However, it resulted in the detention of all those who arrived on the MV Sun Sea and Ocean Lady. Some were detained for a year, which is much longer than the maximum 90 day detention the United Nations (UN) suggests (Poynter, 2012). With the arrival of Tamil asylum seekers, the Canadian government decided new legislation had to be introduced in order to prevent similar situations from reoccurring. This resulted in harsher policies toward asylum seekers with the introduction of Bill C-11 and Bill C-31, which will be analyzed in this study.

\section{Current Study}

The research questions for this study are: how are asylum seekers depicted in political discourse? What is the impact of these discourses on legislation regarding asylum seekers? The word discourse is this paper will refer to specific narratives, concepts and terms which are used by the government. The aim of this major research paper is to explore the representation of asylum seekers in Canadian political discourse, which justifies the recent changes made to asylum legislation. The majority of research on the depiction of asylum seekers in political 
discourse has been conducted in countries such as England and Australia. There has been little research conducted on political discourse on asylum seekers in Canada. For example, Ibrahim (2005) wrote an article "The Securitization of Migration: A Racial Discourse" which included an analysis of how the government depicted Chinese asylum seekers. However, political discourse was not the main focus of the study. Bradimore \& Bauder (2011) "Mystery Ships and the Risky Boat People: Tamil Refugee Migration in the Newsprint Media” also discussed the representation of Tamil asylum seekers in Canadian media. This article is relevant to this study and does allow for some analysis in political discourse, but the main focus was on the media. Media discourse can be viewed as a tool to educate the public and present multiple perspectives on an issues; whereas, political discourse tends not to represent multiple perspectives and seems to have an agenda. This differentiates media and political discourse.

Two other studies conducted examined political discourse: Steele (2013) "Bogus Claim: A discursive analysis of the portrayal of Hungarian Roma Asylum Seeker in Canada" and Conway (2011) "Examining the "Illegitimate" Refugee Label: A case study of Roma Refugee Claimants in Canada, 2008-2009." Both of these studies focused primarily on the Roma and the impact of negative labels used against them in political discourse. The current study is more general and examines the impact political discourse has on all asylum seekers and the asylum system in Canada; therefore, this paper will allow for new knowledge creation. The objective of this paper is to explore how the representation of asylum seekers in political discourse results in the implementation of tougher asylum legislation.

This research area is important to explore because of the recent implementation of two pieces of legislation: The Balanced Refugee Reform Act (Bill C-11, 2012) and Protecting Canada's Immigration System Act (Bill C-31, 2012). These two measures introduced harsher 
laws for asylum seekers. These measures include the designated country of origin policy, mandatory detention of certain groups of irregular arrivals, the inability for certain groups to appeal decisions, faster hearings for refugee claimants and cuts to the Interim Federal Health (IFH) program (Bill C-11, 2010; Bill C-31, 2012). These changes have been successfully enabled by the use of discourse to persuade the Canadian public that asylum seekers represent a threat and changes to the system are required in order for Canada to remain a safe country. This research paper will allow for an in-depth investigation of how political discourse was used to justify the need for implementing Bill C-11 and Bill C-31, as well as why these new changes are exceptional measures and how they violate human rights.

This research paper will begin with a literature review to provide background information on this research area. There will also be a review of previous studies conducted on the representation of asylum seekers in political discourse. These studies will be primarily based on research conducted in Australia and the United Kingdom since there has been little research completed on this topic in Canada. This will allow for an overview of similar themes which have been discovered in regards to the representation of asylum seekers in political discourse.

This paper will then lead into a description of the theoretical framework used for this study. The theory which will be used is the securitization theory, which explores the use of discourse by politicians and other actors to frame issues as threats to security in order to persuade the public into accepting new legislation or exceptional measures (McDonald, 2011). The securitization theory will not only allow insight into the way asylum seekers are represented but how these representations were used to justify legislation such as Bill C-11 and Bill C-31. This will be followed by the methodology section which will outline the types of government 
discourse which were analyzed for this study, and the use of a semantic content analysis to analyze data.

The last section will be the results of the study which involves a discussion of how asylum seekers are represented in political discourse and how the securitization theory explains the implementation of harsher legislation. This includes a discussion about Bill C-11 and Bill C31. A focus will be placed on the designated country of origin policy, the mandatory detention of certain irregular arrivals and the health cuts made to the IFH program. These changes will be examined because they are deemed exceptional and are not consistent with the Canadian Charter of Rights and Freedoms (The Constitutional Act, 1982).

\section{CHAPTER 2: LITERATURE REVIEW}

Previous literature on asylum seeker political discourse has focused primarily in Australia and in Europe. For example, Rowe \& O’Brien (2013) wrote an article called the "Constructions of asylum seekers and refugees in Australian political discourse" and Schech (2010) conducted a study called "Seeing Like a Region: Parliamentary Discourses on Asylum Seekers and Refugees in Scotland and South Australia." The studies have explored parliamentary debates, government speeches and news releases. These articles have conveyed several similar themes on the representation of asylum seekers in political discourse and the processes in which this occurs. These themes and processes will be discussed in this portion of the literature review in order to provide background information on similar findings which have been discovered in this research area. This will assist in guiding and justifying the research approach for this study. 


\section{Representation of Asylum Seekers in Political Discourse: Recurrent Themes}

One common finding was an 'us' vs 'them' framework which was used when discussing asylum seekers in political discourse. Goodman (2007) found that asylum seeker political discourse in England was generally developed with an 'us and 'them' framework in government speeches. Terms such as 'we' were used to represent the general public, citizens of England or the taxpayers; 'them' were used to represent asylum seekers (Goodman, 2007; McKenzie \& Hasmath, 2009). This creates a dichotomy and a conflicting message to the public that asylum seekers and the British population cannot live cohesively together; therefore the general public may begin to hold a negative view of asylum seekers (Goodman, 2007; McKenzie \& Hasmath, 2009). For example, politicians used 'us' when discussing social cohesion and used the word 'them' when alluding to the challenges of social cohesion. This can be interpreted as asylum seekers problematizing the social cohesion which exits in England (Goodman, 2007).

Schech (2010) discovered an 'us' vs ‘them' framework used in Australian political discourse in regards to asylum seekers. The premiere at the time of the study constantly used a binary construction placing asylum seekers in a 'them' position and the Australian population in an 'us' position (Schech, 2010). In this study, the framework 'us' was consistently used to represent the generosity of the people of Australia. This portrayed them in a very positive way by emphasizing their humanitarianism toward asylum seekers (Schech, 2010). Once again, asylum seekers were depicted in a negative manner. For example, the word asylum seeker was replaced with 'them' when discussing the expense asylum seekers would be to Australia and all the support Australia would have to supply for them (Schech, 2010). 
Rosenkranz (2013) explored the representation of asylum seekers in South African political discourse. Once again an 'us' vs 'them' framework was used. This study found that terms such as 'us', 'we' and 'our' were used in opposition to 'those refugees', 'these people' and 'these persons' or 'the refugee'. The 'us' vs 'them' words were contrasted against each other in a negative way. For example, words such as 'those refugees' were referred to when discussing the economic drain they would have on the country and what they would take away from 'us' (Rosenkranz, 2013). This created a distinct separation between the people of South Africa and asylum seekers. By using this binary framework, asylum seekers were not represented in a positive manner (Rosenkranz, 2013).

A second theme is the amount of emphasis placed on the generosity and humanitarianism in asylum seeker political discourse. Every \& Augoustinos (2008) discovered that politicians on any side of a debate about asylum seekers would constantly emphasize the generosity of Australia toward all migrants and refugees (Every \& Augoustinos, 2008). The government in the United Kingdom have also emphasized continuously their generosity toward asylum seekers in their political discourse. The government has asserted its commitment and tradition in protecting asylum seekers (Schech, 2010). Similar statements have been found in South African discourse, where the number of asylum seekers accepted into the country and the kindness of the country toward asylum seekers has been highlighted (Rosenkranz, 2013). Boat people were accused of trying to exploit Australia's compassion and generosity (McKenzie \& Hasmath, 2013).

The emphasis on Australia's generosity toward asylum seekers has been used to create a tougher asylum system and a positive representation of the country's generosity and humanitarianism (Every \& Augoustinos, 2008). This is commonly followed by negative 
representations of asylum seekers (McKenzie \& Hasmath, 2013). For example, there would be an emphasis placed on how welcoming Australia is toward asylum seeker, which would be followed by accusations of asylum seekers exploiting Australia's generosity (McKenzie \& Hasmath, 2013). Also mentioned was the ability of Australia to still be generous and meet their humanitarian commitment by creating a tougher system which could not be abused by asylum seekers (Every \& Augoustinos, 2008).

To support the creation of tougher legislation, statements were made in regards to Australia doing 'more than enough' and fulfilling their international commitment toward asylum seekers (Every \& Augoustinos, 2008). Also, statements were made along the lines of it not being Australia's responsibility to resettle asylum seekers, and that the country has been more than generous. These types of statements convey that Australia has played a substantial role in accepting asylum seekers and they should not have to be responsible in continuing to accept all asylum seekers who enter the country. This type of discourse was used to justify harsher asylum seeking policies (Every \& Augoustinos, 2008).

Statements such as 'being one of the most generous countries in the world' has been used in South Africa (Rosenkranz, 2013). These types of statements convey that politician's feel they have met their humanitarian role by admitting their share of asylum seekers into the country and that they can no longer carry the burden of continuing to allow asylum seekers into the country (Rosenkranz, 2013). These types of discourses validate reasons for tougher laws to be created toward asylum seekers (Every \& Augoustinos, 2008).

A theme which was found to be used quite consistently in political discourse in regards to asylum seekers who arrive by boat is a fair system. The Australian system has repeatedly been 
referred to as 'fair go' on the basis that those seeking asylum apply for protection offshore rather than onshore (Every \& Augoustinos, 2008). Asylum seekers who arrive by boat are discussed as violating the egalitarian system, which Australians place a strong value on and take great pride in. This creates a positive-negative contrast and relates to the 'us' vs 'them' theme discussed earlier (Schech, 2010).

Asylum seekers who arrive by boat are presented as not being fair while Australia is being fair, because they have created procedures for asylum seekers to follow in order to be declared refugees and be admitted into the country. This involves asylum seekers completing an application offshore and once the application has been approved by the Australian government, then asylum seekers may enter the country legally as refugees. Asylum seekers who arrive by boat are not deemed as being fair because they have entered the country without permission and without going through the application process. This discourse results in Australians feeling that asylum seekers who arrive by boat should not be treated fairly because they have not entered the country according to the fair asylum seeker application system (Every \& Augoustinos, 2008).

Also, with this type of discourse, asylum seekers who arrive by boat are presented as people who have the opportunity to complete the necessary procedures in order to seek asylum in Australia. This means they are viewed as having the ability to stay offshore and complete an application, but they have decided to cheat the fair system and arrive to Australia by boat without legally receiving permission from the Australian government. However, asylum seekers may not have the opportunity to stay offshore and apply for asylum depending on their reason for seeking asylum (Every \& Augoustinos, 2008). Political discourse on asylum seekers who arrive by boat implies that asylum seekers left their country by choice and not by force. Therefore, asylum 
seekers are accused of violating the fair system that Australia has implemented (Every \& Augoustinos, 2008).

Another term which is used when discussing a fair system in political discourse is 'queue jumper' (McKenzie \& Hasmath, 2009). This term is in references to those who are in refugee camps waiting to be recognized as refugees, and then resettle in a third country such as Australia or the United Kingdom. Asylum seekers who arrive in an irregular manner such as by boat are considered queue jumpers because they have not waited in camps to be resettled. A queue is defined as being fair, rational and in accordance to the rules. Jumping the queue is deemed as a violation of fairness; therefore, a queue jumper is viewed as someone who has broken the rules (Every \& Augoustinos, 2008). A queue represents a fair system and a queue jumper represents someone who has broken the rules and arrived in an irregular manner; therefore, some asylum seekers are deemed as not playing fair (McKenzie \& Hasmath, 2009).

A few articles placed an emphasis on the burden asylum seekers would be on the economy. Ibrahim (2005) found that the government constructed asylum seekers as a burden on the economy and described them as destroying the welfare system in Canada. Discourse was used to place fear in Canadians that there was not enough money to cover the costs of asylum seekers, especially those arriving by boat. Asylum seekers were represented as an economic strain (Ibrahim, 2005).

The United Kingdom and Australia have represented asylum seekers in a similar way. For example, politicians argued that it was unreasonable to accept asylum seekers because of the financial constraints the country was already in because of previous acceptance of asylum seekers (Every \& Augoustinos, 2008). Also, political discourse was used to portray people of 
Australia and the United Kingdom as victims to the expense of asylum seekers. An emphasis has been placed on the burden they will be on society and taxpayers (Schech, 2010). Politicians have used financial strain as a way to justify the harsh treatment toward asylum seekers and as a reason to prevent asylum seekers from seeking refuge (Every \& Augoustinos, 2008).

In political discourse, several terms which are considered damaging have been used when describing asylum seekers. This section on negative labels is about the process which occurs through political discourse to portray asylum seekers negatively. These negative names included: illegitimate, irregular, illegal, boat arrivals, bogus and queue jumpers. These terms were used in contrast to positive terms such as legitimate, legal, genuine and good (Rowe \& O'Brien, 2013). There is a strong use of oppositional terms in asylum seeker political discourse (Babacan, 2007). The mode of arrival has a profound influence on how certain groups of asylum seekers will be presented by the government and accepted by the public. A dichotomy is usually created between asylum seekers who arrive in Australia without permission and those who apply offshore. Therefore, there are either legitimate genuine humanitarian refugees or illegitimate boat arrivals (Rowe \& O’Brien, 2013).

The negative labels asylum seekers receive are sometimes used incorrectly by politicians. For example, asylum seekers, who are individuals claiming they need international protection, are sometimes referred to as irregular migrants. Irregular migrants are not seeking protection but are people who leave their country of origin primarily for economic reasons such as to find employment in the receiving country. These individuals can also be referred to as undocumented migrants because they have unauthorized employment. By labeling asylum seekers as irregular migrants, they are being depicted as individuals looking for employment and economic gain rather than protection from persecution. When asylum seekers do seek protection, all the rights 
and guarantees set forth in the 1951 Refugee Convention apply and should be respected because of international obligations by states (UNHRC, 1951).

Those who arrive by boat are viewed as jumping the queue. As discussed earlier, this label is given to asylum seekers who are viewed to have broken the rules and arrived onshore instead of applying for protection offshore (McKenzie \& Hasmath, 2009). Once asylum seekers are portrayed as jumping the queue, they are no longer viewed as genuine (Babacan, 2007). It was also discovered that words such as undeserving are attached to those who jump the queue; therefore, there is little or no compassion given toward them. Those who jumped the queue are contrasted to those who went through the fair system of migration and the two groups are placed in contrast to one another (Rowe \& O'Brien, 2013).

Once the mode of arrival has been determined, politicians continue to use negative labels for those who arrived by boat. One term used is illegal, which is usually used in opposition to the term legal. The term illegal delegitimizes those who arrive by boat. This is because the term can imply that those who arrive by boat do not belong because they have committed a crime or because they have wronged someone (Bauder, 2013). Also, the word illegal can place blame on those seeking asylum for being in the situation they are experiencing. The term results in negative views and attitude toward asylum seekers (Bauder, 2013). This creates the impression of a value system of certain asylum seekers being criminals and others not. Once asylum seekers are viewed as criminals, they are deemed a threat to the country (Rowe \& O'Brien, 2013). This situation usually creates public outcry and a fear of those who arrive by boat (Fitzgerald, 2013). This will be further discussed later in the literature review. 
The creation of oppositional terms such as legal and illegal or legitimate and illegitimate in political discourse creates a hierarchy among asylum seekers (Rosenkranz, 2013). Those who arrive by boat are considered undeserving, non-genuine and are viewed as abusing system. Therefore, they are at the bottom of the hierarchy of asylum seekers because they have not followed the procedures implemented for asylum seekers to achieve refugee status in another country. Those who apply for protection in accordance to the system are portrayed as genuine refugees in political discourse (Rosenkranz, 2013). As a result, those who claim asylum offshore are placed higher on the asylum seeker hierarchy than boat arrivals. Those who have been accepted as refugees are viewed in a more positive manner and in need of more protection (Rosenkranz, 2013).

Asylum seekers have been consistently portrayed as a threat in political discourse. Asylum seekers are depicted as threats to nations in several ways. They can be viewed as a criminal or security threats, a threat to the sovereignty of a country and a threat to social cohesion or the identity of a country. Political discourse is structured in a way where the public is made to feel afraid of asylum seekers (Babacan, 2007).

Speeches by government officials in Australia constantly refer to asylum seekers as threats. For example, politicians emphasize that there are asylum seekers in their detention centres who have not been cleared because they may have been involved in criminal activity. If they appeal, they could be cleared and accepted into the community and represent a possible danger to the people of Australia (Every \& Augoustinos, 2008). This type of discourse has created a great amount of panic among Australians (Every \& Augoustinos, 2008). Australians fear that their national identity is at risk because of boat arrivals from Asia and the Middle East. They fear large groups of non-white individuals entering the country are changing the racial 
demographics of the Australian population (Every \& Augoustinos, 2008). In political discourse, asylum seekers are questioned on their willingness to integrate to Australian society, therefore threatening the national identity (McDonald, 2013). Government discourse also emphasizes that asylum seekers are a threat to Australia's sovereignty. Australia is portrayed as insecure and vulnerable to losing its independence because it is not being assertive toward asylum seekers; therefore, the government must instill tougher legislation in order to remain a sovereign country with a cohesive national identity (McKenzie \& Hasmath, 2013).

Asylum seekers are represented as a border-security threat linked to terrorism in Australia, which also threatens the sovereignty of the country and further establishes a negative depiction of asylum seekers (McDonald, 2011). They have also been viewed as a criminal threat because of migrant smuggling (McKenzie \& Hasmath, 2013). Migrant smuggling has been described by the government as criminal as well as evil because migrant smugglers are depicted as individuals who have smuggled migrants for no reason other than their interest in profiteering. Those who are involved in migrant smuggling are depicted as individuals who 'profit, tirade and prey on human misery and the desperation of others.' Even before boats reach their country of destination, criminal investigations are launched on passengers on the boats for criminal activity (Ibrahim, 2009). Migrant smugglers are always discussed in a negative manner and are demonized in political discourse, which creates a negative perspective on anyone who arrives on boats seeking asylum (McKenzie \& Hasmath, 2013).

There have been several themes discovered from previous literature on the depiction of asylum seekers in political discourse. There exists an 'us' vs 'them' framework where asylum seekers and the general public are depicted as indifferent (Goodman, 2007). Also, politicians in countries that are receiving asylum seekers depict themselves as very genuine with a fair asylum 
system in place that is cheated by those who arrive on boats (Schech, 2010). Asylum seekers who arrive by boat are given negative labels and depicted as illegal, human smugglers, and undeserving of protection (Rowe \& O'Brien, 2013). Lastly, a major theme found was the depiction of asylum seekers as threats to the economy, national identity, and national security (Babacan, 2007).

After conducting this literature review, it can be concluded that terms, concepts and narratives in political discourse are used to depict asylum seekers in a negative manner. There is very little discussion on the experiences of asylum seekers and difficulties they may be enduring. Discourse has been used as a weapon to delegitimize asylum seekers to the public, especially those who arrive by boat. This results is very harsh policies for asylum seekers. A majority of these studies have been conducted in countries outside of Canada, which creates a gap in the literature. This study will explore the representation of asylum seekers in Canadian political discourse and will attempt to fill in the gap.

\section{CHAPTER 3: THEORETICAL FRAMEWORK}

The theoretical framework for this paper is securitization theory. Securitization theory originates from the Copenhagen School of Securitization Studies, and was first developed in the mid-1990s by Ole Waever (McDonald, 2011). It is based on conveying issues into security threats with the use of linguistics, specifically through speech acts. In other words, language is used as a tool to portray something as a threat (McDonald, 2011). This theory implies that just by uttering the word 'security' conveys a feeling that something must be done to prevent an existential threat. By labelling something a security threat, it automatically becomes one (Taureck, 2006). There are specific processes which take place in order to successfully portray 
something as an existential threat, gain public support for it and then implement exceptional measures to deal with the threat (Buzan, Waever \& Wilde, 1998).

The securitization theory states that specific actors must be involved. Firstly, agents or securitizing actors are political leaders or elites, and the audience refers to the general public (Karyotis, 2012). Securitization theory is a top-down process. Political leaders frame an issue to the public as an existential threat to the fundamental values of society and the country, which needs to be urgently dealt with (Karyotis, 2012). This means discourse must be presented in a way where there is a threat and there is no point of return (Leonard, 2007). The issue or threat is usually dramatized and depicted as a supreme priority that goes beyond politics and thus needs extraordinary measures to treat it (Buzan et al., 1998). This assists in convincing the audience that exceptional measures need to be taken in order to deal with the threat (Buzan et al., 1998) If the public agrees the issue is an urgent threat, a securitization move such as policy changes can be made (Karyotis, 2012). This results in exceptional measures to be implemented in order to deter or resolve the threat (McDonald, 2011). The securitization move or the measures put in place usually goes beyond the political process and law and can involve breaking the rules by violating human rights and international treaties (Buzan et al., 1998).

The Copenhagen School emphasizes the importance of recognizing the existential threats which exist in political discourse. However, the securitization theory also places an emphasis on the process where an issue becomes a security threat (Leonard, 2007). It important to analyze the way agents can successfully speak about security threats and implement exceptional measures (Buzan et al., 1998). Therefore, the Copenhagen School's securitization framework focuses on how something becomes a security threat and the extraordinary measures which are implemented to deal with the threat (Leonard, 2007). 
The securitization theory applies to asylum seekers because migration has been designed as a security threat. For example, in Europe, policies in regards to migration became an issue of debate as migration increased in the 1980s (Van Dijk, 2006). The debates revolved around migration being a problem to the welfare state, cultural composition of countries and of the danger migrants may bring to receiving countries (Van Dijk, 2006). The focus of these policy debates was placed primarily on the possibility of migrants being a security issue. The security issue then became the backbone of immigration policies in Europe. The regulation of migration for security purposes became the framework when developing new legislation for migration. In Europe, this framework introduced policies which connected immigration and asylum seekers to terrorism, transnational crime and border protection (Seidman-Zager, 2010).

The narratives used in political discourse are vital in order to present migrants as possible security threats and for tougher legislation on migration to be passed. As mentioned above, the idea of migrants even presenting a security threat was derived from political debates, which is political discourse (Seidman-Zager, 2010). Security discourses in regards to migration are frequently presented as an issue which requires policy changes in order to maintain public order and as a way to control the higher number of migrants and asylum seekers entering a country. This process exemplifies how a security issue elicits a security policy (Huysmans, 2000). Political discourse presents policy as a tool for safety and protection from the invasion of asylum seekers and the dangers that migrants may bring. In other words, the process of presenting migration as a securitization issue involves the use of specific narratives in political discourse to create or present a problem and then solve the problem with policy (Huysmans, 2000).

Policies are usually derived from government departments which are responsible for regulating migration such as Foreign Affairs or Immigration (Huysmans, 2000). The focus of 
these government institutions is to produce security knowledge. Therefore, they are pre conditioned to present security issues into political discourse and implement measures in order to prevent security threats. This allows for the representation of asylum seekers and immigrants to be viewed as a security threat (Huysmans, 2000).

In terms of the results of the securitization, Australia offers an example of the securitization of migration (McDonald, 2011). Those in position of authority have continuously used speech-acts to portray asylum seekers as threats to Australia's identity, security and sovereignty. This portrayal was discussed in the literature review. The Australian government placed an emphasis on boat arrivals and on the large number of asylum seekers entering the country and the threat they cause (McDonald, 2011). There was also mention that terrorist could be among the boat arrivals. This created a feeling of immediate existential threat. The solution to these security threats were presented as policy changes. The use of emergency measures were continuously reiterated by the government and gained public support. These measures resulted in naval blockades, the suspension of the media to talk to asylum seekers and harsher detention practices (McDonald, 2011).

The changes in Australia's asylum system over the past ten to fifteen years have been quite dramatic (Tuckfield, 2014). Australia is said to have one of the strictest immigration detention regimes in the world. Detention is mandatory for all boat arrivals including children in Australia. Also, boat arrivals are placed in processing centres in third world countries outside of Australia such as Nauru and Papua New Guinea where conditions are very harsh. This has resulted in severe psychological disorders such as depression and anxiety among those in detention (Tuckerfield, 2014). There is also no time limit for detention and those who arrive by boat cannot challenge their detention to the courts. The prolonged and indefinite detention of 
asylum seekers encourages long delays in processing claims (Tuckfield, 2014). These changes are an example of the consequences of presenting asylum seekers as security threats.

Securitization theory relates to the representation of asylum seekers in political discourse. As discussed in the literature review portion of this paper, asylum seekers have been portrayed in a very negative manner. Language has been used to depict asylum seekers as threats to the economy, national identity and sovereignty (Babacan, 2007). Asylum seekers who arrive by boats are also labelled as illegal, terrorists, criminal, and portrayed as evil human smugglers who are entering the receiving country (McKenzie \& Hasmath, 2013). Through language, the government presents asylum seekers as threats to the public, who then begin to fear asylum seekers. The public then provides approval for exceptional measures to be taken in order to stop the threat of asylum seekers. These measures include harsher legislation and policies toward asylum seekers (Every \& Augoustinos, 2008).

\section{CHAPTER 4: METHODOLOGY}

\section{Approach}

The approach that was taken for this study was qualitative. This is because the research questions are exploratory and open-ended with the data being primarily in narrative form (Huberman \& Miles, 1994). Another reason the approach is qualitative is because this study will be generating new interpretation of data by examining news releases, statements, speeches and backgrounders released by the Ministry of Citizenship and Immigration and by the Ministry of Public Safety between 2009 and 2012, which have not been researched yet. Lastly, this research study is qualitative because it will be examining how something is shaped, which for this study is investigating how asylum seekers are depicted in Canadian political discourse. Therefore, this 
study will generate knowledge on how political discourse portrays asylum seekers in Canada and how this has justified the adoption of Bill C-31 and Bill C-11 (Huberman \& Miles, 1994).

\section{$\underline{\text { Strategy }}$}

The strategy that was used is content analysis. Content analysis is a research method which allows for the interpretation of text data through a systematic classification process of coding and identifying themes (Mayring, 2000). Qualitative content analysis does not just involve counting words; it is about finding themes and patterns that allows researchers to understand the social issue or problem being examined in a scientific manner (Mayring, 2000).

Content analysis is used to detect the use of propaganda and to identify its intention or focus. It is also used to analyze the attitude and behavioural responses to communication. A content analysis is an excellent method for this study because it focuses on political discourse and the behavioural response to it, which is the introduction of exceptional measures. A content analysis correlates very well with the securitization theory because it examines the relationship between communication provided by an institution and the impact it has on people and legislation (Busch, De Maret, Flynn, Kellum, Le, Meyers, Sanders, White, \& Palmquist, 2012).

This study used a semantic or relational content analysis. A semantic content analysis was used to examine the relationships among concepts in the text and goes beyond just identifying them (Busch et al., 2012). Individual concepts do not inherent meaning. Meaning is created by examining how concepts are used together in text. This methodology was chosen because the goal of the study is to examine what types of messages are being delivered to the public from the government and the type of reaction it entices (Busch et al., 2012). 
A qualitative content analysis was taken because it allowed for careful examination of text data. The initial coding for the semantic content analysis was based on the major themes discovered in the literature review such as generosity, a fair system, threats, etc. Then through the constant analysis, more themes or different themes were discovered in the political discourse such as the abuse of the system. This resulted in new codes. This strategy was taken in order to analyze text and guide research in a way that is unbiased.

\section{$\underline{\text { Sample }}$}

The sample was text released by the Canadian government. This included any text released by the government in relation to asylum seekers and human smugglers. The sample came from the Ministry of Citizenship and Immigration because it is responsible for developing and implementing policies, programs and services that: facilitate the arrival of people and their integration into Canada in a way that maximizes their contribution to the country while protecting the health, safety and security of Canadians; maintain Canada's humanitarian tradition by protecting refugees and people in need of protection; enhance the values and promote the rights and responsibilities of Canadian citizenship; and reach out to all Canadians and foster increased intercultural understanding and an integrated society with equal opportunity for all, regardless of race, ethnicity and religion (Ministry of Citizenship and Immigration, 2014).

The sample also came from the Ministry of Public Safety. This department released discourse on the boat arrivals of asylum seekers in 2009 and 2010 because it was suspected that those on the boats belonged to the LTTE and they could be a possible security threat. Therefore, there was discourse available on legislative measures targeting terrorists and smugglers, which is 
relevant to this study. By using these two samples it allowed this study to remain focused on the research goals.

The time period chosen was between 2009 and 2012 because it corresponds with the time period when the Ocean Lady and MV Sun Sea arrived in Vancouver. At this time, there was widespread public debate on how to respond to those who arrived on the boat such as whether or not to accept their claims, if they posed a security threat to Canada and if they should be placed in detention. Therefore, there was political discussion available on the depiction of asylum seekers. Also, this allowed for the collection of recent data and ensured that there was data available in order to conduct this study. During this time period, Bill C-31 and C-11were introduced as a result of the boat arrivals. This is relevant to this study in order to understand the depiction of asylum seekers and how it influenced new legislation to be introduced.

Articles were collected by using government websites. Both the website for the Ministry of Public Safety and Citizenship and Immigration were used. It was deemed that these two websites would contain information related to the study because they are the two government department which are responsible for security and asylum seekers. Once on these websites, archived data was searched in order to find data where there was discussion of asylum seekers and human smuggler between 2009 and 2012. Then news releases, speeches, statements, and backgrounders where reviewed in order to find those that were related to this study. Those which contained key words such as: asylum seekers, refugees, Bill C-31, Bill C-11, human smuggler, security threat, terrorism, boarder security, boat arrivals, Ocean Lady, MV Sun Sea and LTTE were collected. These key terms were used because of the findings in the literature review. In total, the sample consisted of 28 articles. 


\section{Data Collection Tool}

The original data collection tool which was used for this study can be viewed in the appendix. The initial observational guide for the semantic content analysis was a chart. The chart included information on the website the article was obtained from, type of article is was (news release, speech, etc.) title of the article, the date it was released, who was discussed, if an 'us' vs 'them' framework was used, any emphasis on generosity, mention of a fair system, the economic impact of asylum seekers, if any negative labels were used, if asylum seekers were deemed as a threat, mention of Bill C-31 or Bill C-11 and any other section for any other important findings that could be used to possibly create new themes and codes. There were examples given under each of these sections. A limitation of the tool is that it may have been missing important codes or themes which are relevant to the depiction of asylum seekers in Canada. Hopefully, by the inclusion of the 'other' section, any codes of themes that were missing were identified. Changes were made to the data collection tool accordingly.

\section{Data Organization}

Data was organized into charts. As mentioned in the above section, a chart was created for each article analyzed. The charts were organized into folders based on which government website they were obtained from. In each of these folders, the articles were organized based on what type of article they were. For example, all backgrounders were paper-clipped together, all speeches were placed together, etc. Each paper-clipped bundle was organized in chronological order from the oldest to the most recent article from 2009 to 2012. 
Analysis

The unit of analysis was any length of text; this included a word, sentence, or even a paragraph. The first step in the data analysis for the relational content analysis was conceptualization (Neuman, 2006). This step involved creating new ideas from what the data is conveying. This means new words, terms and ideas were created, which resulted in concepts; for example, the word abuse was continuously used and resulted in the abuse of the system concept. The next step involved refining the new concepts discovered by finding more detail about the concepts and the relationships which existed between them. This included the process of making linkages between how concepts which are related to each other may impact on another; for example, making a connection between the constant use of the word abuse and the solution of new legislation to deter this problem (Neuman, 2006).

The next step involved creating codes (Neuman, 2006). There were three types of coding carried out: open coding, axial coding and selective coding. Open coding was the first time the data was read through. This was the initial process of condensing information into categories. This process involved highlighting different concepts in different colours and keeping a legend of what each coloured highlighter represented; for example, purple highlighter was used on any text which depicted asylum seekers as an economic burden. By open coding, new themes which existed under the surface arouse (Neuman, 2006). There were several themes discovered during this process. These themes included an emphasis on Canada's compassionate nature, negative depiction of human smugglers, discussion of the recent boat arrivals, arrests made, the urgency for a new Bill to be introduced, security of borders etc. 
The next step in analysis was axial coding. Axial coding occurred during the second review of the data (Neuman, 2006). The focus during this stage was on the themes that were identified during open coding. Here existing categories were divided into subcategories, concepts were combined, themes were dropped, and comparisons were made between themes. During this process, themes such as human smuggler and the security of borders were combined into a major heading of threats. Evidence was also found for themes to strengthen the relationship between data and themes (Neuman, 2006).

The last type of coding was selective coding. Selective coding was established at the last read through of the data (Neuman, 2006). The major themes were identified by this stage. Examples were collected from data to illustrate the claims being made. Themes were also analyzed in terms of theoretical framework and how they connect; for example, connections were made between the threats asylum seekers were depicted as being and the solution offered by the adoption of Bill C-31 and Bill C-11. In this stage, information was identified to explain or answer the research question and make conclusions (Neuman, 2006). Here, excerpts were selected to provide examples for themes such as discussion about the despicable nature of human smuggling for the threats theme. This also assisted with making connections to the securitization theory. This finalized the analysis process.

\section{$\underline{\text { Limitations }}$}

There are limitations to this research study. Firstly, the observational guide which was created may have overlooked some themes. Another limitation of this study is the scarcity of scholarly publication on this subject in Canada. This includes articles on the recent reforms to the Canadian asylum system such as detention and the fight against human smugglers. 


\section{CHAPTER 5: RESULTS PART I - REPRESENTATION OF ASYLUM SEEKERS}

The results section will be divided into two chapters in order to answer the research questions proposed in the beginning of the paper. The first chapter of the results will focus on how asylum seekers were depicted in political discourse. Many of these findings correlate with the themes discussed in the literature review, but there are also some new findings. The second part of the results will focus on the impact of political discourse on Canada's asylum system. This involves a discussion of the exceptional measures implemented for those seeking asylum and how they violate human rights.

\section{Emphasis on Generosity}

There were several findings discovered in Canadian political discourse which were related to the literature review. Previous research found that political discourse placed a strong emphasis on the generosity of a country (Every \& Augoustinos, 2008). The same was found for Canada. The following quotes illustrate the way Canadian political discourse continuously highlights the generosity of Canada:

Canada is a compassionate nation of immigrants with a proud history and tradition of welcoming refugees (Ministry of Public Safety, 2011c).

Canada is a generous and compassionate country that welcomes newcomers (Ministry of Public Security, 2012a).

Canada has a longstanding reputation as a generous and compassionate country that welcomes newcomers (Ministry of Public Safety, 2012b).

Canada has one of the most generous immigration systems in the world (Ministry of Public Safety, 2012f)

Canada welcomes thousands of new immigrants and refugees every year through one of the most generous refugee systems in the world. This is a source of pride for our government and a reflection of the generosity of our nation (Ministry of Public Safety, 2010). 
Canadians take great pride in the generosity and compassion of our immigration and refugee programs (Ministry of Citizenship and Immigration, 2012a).

Canada has a long tradition of helping people from around the world who seek protection (Ministry of Citizenship and Immigration, 2010e).

The above quotes constantly depict Canada as a generous and compassionate country that has a tradition of helping refugees, which is true. This type of narrative recalls to the public that Canada has a history of helping refugees and has been fulfilling its humanitarian duty. Previous literature has found that placing an emphasis on the generosity of a country can be used as a method to implement tougher legislation in regards to asylum seekers (Every \& Augoustinos, 2008). Canadian political discourse definitely seems to follow this pattern, since the above statements were made in order to implement Bill C-11 and Bill C-31. This suggests that Canada needs to protect itself from being further victimized by asylum seekers who arrive by boat. Asylum seekers are represented in political discourse as abusing the system, destroying the fairness of the system, draining the economy, and by posing as a safety risk to Canada; this constructs asylum seekers as a threat to Canada.

\section{Abuse of the System}

There were a few new themes which were discovered in this study, which were not found in previous literature. One of those themes was abuse of the immigration system. The following passages exemplify this:

Canadians gave us a strong mandate to prevent the abuse of our generous immigration system. Canadians have told us this abuse of our generosity is a real problem that must be stopped (Ministry of Public Safety, 2011c).

Human smuggling is a deliberate abuse of our immigration system and refugee process (Ministry of Public Safety, 2012c). 
Yes, Canada is a welcoming nation but our government has clearly stated that we will not tolerate the abuse of our immigration system either by human smugglers or by those who are unwilling to play by the rules (Ministry of Public Safety, 2010).

Human smuggling and other abuses of Canada's immigration system cannot and will not be tolerated, said Minister Moore. "Our government's action will prevent the abuse of Canada's immigration system by human smugglers (Ministry of Citizenship and Immigration, 2010b).

We need to send a message to those who would abuse Canada's generous asylum system that if you are not in need of protection, you will be sent home quickly (Ministry of Citizenship and Immigration, 2012a).

The above excerpts portray Canada as a nation which is being mistreated by human smugglers and asylum seekers because they are taking advantage of the immigration system. This presents Canada as a victim and those involved with human smuggling as victimizers. This is emphasized by depicting Canada as generous and then representing human smugglers and asylum seekers as abusers. This relates to the 'us' vs 'them' framework (Goodman, 2007). 'Us' represents Canadians and 'them' represents asylum seekers. This 'others' asylum seekers as if they are not similar to Canadians because they abuse the system and therefore are undeserving of protection. This is further developed by the emphasis placed on Canadians unwilling to tolerate the abuse. This portrays Canadians as good humanitarians and asylum seekers and human smugglers as abusers (Goodman, 2007).

Another way in which political discourse portrays human smugglers as abusers is by claiming they are only interested in profiteering. These narratives present asylum seekers as victims. However, the emphasis is placed on the profiteering of human smugglers and not the physical or mental health issues asylum seekers experience. By highlighting the profiteering of human smugglers, the government justifies tougher asylum policies to protect them from human smugglers. However, these measures usually further victimize asylum seekers instead of protecting them. The following passages illustrate this: 
No Canadian thinks it's acceptable for criminals to abuse Canada's immigration system for financial gain (Ministry of Public Safety, 2011c).

But no Canadian thinks it's acceptable to abuse our immigration system for financial gain through human smuggling (Ministry of Public Safety, 2012a).

Canadians will not tolerate abuse of our immigration system for financial gain through the despicable crime of migrant smuggling (Ministry of Public Safety, 2012b).

Our Government is committed to putting an end to the misery and profiteering associated with these heinous acts (Ministry of Public Safety, 2012d).

Human smuggling is a criminal enterprise that spans the globe. It involves organizing the illegal entry of persons into a country in order to receive a financial or other material benefit. By charging people large sums of money for their transportation, human smugglers have made a lucrative business out of facilitating illegal migration, often by counselling smuggled persons to claim asylum in the country to which they are smuggled (Ministry of Citizenship and Immigration, 2012e)

In the above excerpts, asylum seekers are depicted as presenting false claims, which can also be deemed as abuse of Canada's immigration system. This allows stronger justification for the detention of asylum seekers in order to ensure that they are not using false claims to live in Canada.

Passages like the following are also used to represent migrant smugglers in a negative manner and as abusers of the system:

The MV Sun Sea was a migrant vessel that brought 492 irregular migrants to Canada in August of 2010 as part of a migrant smuggling event. With this latest arrest, a total of five men have now been arrested for their involvement, four of whom are currently in Canadian police custody and one of whom is facing extradition from France. A sixth man is not believed to be in Canada and there is a Canada-wide warrant out for his arrest (Ministry of Public Safety, 2012b).

This excerpt emphasizes the number of irregular migrants entering Canada and the arrests that have been made. Therefore, it highlights the number of asylum seekers who are abusing the immigration system and then that is reinforced by discussing the arrests of human smugglers. 
Discourses like the above overemphasize the number of irregular migrants entering Canada. This creates moral panic among the public because it implies that the system is overburdened by those who arrive by boat. However, in reality, boat arrivals in Canada represent a small percentage of all asylum seekers and this is not as imminent of a problem as the narratives used in political discourse perceive it to be. Those who arrived on the Ocean Lady were the first refugees to arrive by boat to Canada in 20 years (Canadian Tamil Congress, 2010). Also, by referring to asylum seekers as irregular they are delegitimized. This has a negative impact on asylum seekers because they are then viewed as criminals or as not deserving of asylum (Bauder, 2013). The consistent representation of those involved with human smuggling as abusers of the immigration system depicts them in a very undesirable manner.

\section{$\underline{\text { Economic Impact }}$}

A third common finding between previous literature and this study is the economic impact of asylum seekers. The following quotes emphasize the waste of money asylum seekers are deemed as:

In recent years over $95 \%$ of EU claims were withdrawn, abandoned or rejected. If that trend continues, that means that the unfounded claims from the 5,800 EU nationals who sought asylum last year will cost Canadian taxpayers nearly $\$ 170$ million (Ministry of Citizenship and Immigration, 2012a).

Too many tax dollars are spent on bogus refugees (Ministry of Citizenship and Immigration, 2012a).

We're spending far too much time and taxpayers' money on bogus claims, and on generous tax-funded health and social benefits for claimants from liberal democracies (Ministry of Citizenship and Immigration, 2012b).

The above quotes continuously highlighted the amount of taxpayer money spent on unfounded asylum claims. This type of narrative has two implications. Firstly, an emphasis placed on the 
number of unfounded or 'bogus' claims portrays all asylum seekers as individuals to be suspicious of and in a negative manner. This is related to the theme of negative labels which was discussed in the literature review. Besides 'bogus,' other words which were used to describe asylum seekers were: fraudsters, illegal and illegitimate. These words delegitimize asylum seekers, especially those who arrive by boat (Rosenkranz, 2013).

The second implication is that asylum seekers are deemed as a waste of money and as individuals who are trying to benefit or reap from Canada's health and social benefits. This type of narrative takes a few cases and generalizes them to the entire asylum seeker population. For example, one of the excerpts from above mentions that $95 \%$ of asylum-seeker claims from the European Union (EU) go unfounded. However, there are still groups of people being persecuted in the EU such as the Roma, who should not be ignored (Chase, 2013). This depicts asylum seekers as individuals just trying to take advantage of the benefits Canada provides for its residents.

The following quotes also highlight the economic impact of asylum seekers:

With the Balanced Refugee Reform Act and today's legislation, the provinces and territories are expected to save in the range of $\$ 1.65$ billion over five years in social assistance and education costs (Ministry of Citizenship and Immigration, 2012a).

The Protecting Canada's Immigration System Act is expected to save provinces and territories $\$ 1.6$ billion over five years in social assistance and education costs (Ministry of Citizenship and Immigration, 2012b).

These passages focused on the money that could be saved by implementing new legislation. It again suggests that asylum seekers are a drain to the system and to taxpayer. By the implementation of new laws large sums of money could be saved. This relates to discourse in the 
United Kingdom where financial constraints are blamed on previous asylum seekers and then is used as an excuse to justify tougher legislation in order to save money (Schech, 2010).

\section{Threats}

Both previous literature and this study found that political discourse continuously depicted asylum seekers as threats. The narratives in this section refer to human smugglers, not directly to asylum seekers, but it is still related to this study. The threat is not asylum seekers but smugglers who are a part of crime organizations and networks. The following passages depict human smugglers as threats to Canada.

We will crack down on those who endanger human lives and threaten the integrity of our borders (Ministry of Public Safety, 2011c).

Every sovereign country has a responsibility to protect its borders, (Ministry of Public Safety, 2011c).

We see that Canada is a target for increasingly sophisticated global human smuggling networks and further action is needed now (Ministry of Public Safety, 2011a).

Canada is well-known for its reputation as a tolerant nation, one that welcomes newcomers from all parts of the globe. Unfortunately, this reputation has also made us a target for criminal syndicates. These criminals carry out human smuggling operations that threaten the integrity of our immigration system (Ministry of Public Safety, 2012e).

Human smuggling is a dangerous and despicable crime - it puts lives at risk and threatens the integrity of Canada's immigration system as well as the security and safety of Canadians (Ministry of Public Safety, 2012f).

Human smuggling undermines Canada's security. Large scale arrivals make it particularly difficult to properly investigate whether those who arrive, including the smugglers themselves, pose risks to Canada on the basis of either criminality or national security (Ministry of Citizenship and Immigration, 2012d). 
From the above excerpts, it is important to note that the concepts and terms used continuously refers to criminality, risk, sophisticated global networks and the targeting of Canada. This type of discourse places a negative perception on all boat arrivals. It is also important to take into account that migrant smuggling and human trafficking are words used interchangeably; however, the two words have different meanings. According to the UN, migrant smuggling refers to the payment of money or some other form of material benefit in order for a person to gain illegal entry into a country where that person is not a resident. Human trafficking is when a person is forcibly recruited, transported and transferred by threat or force by another person in order to gain control over them and exploit them for reasons such as prostitution (United Nations Convention against Transnational Organized Crime and the Protocols Thereto, 2000, art 3). Therefore, it is not correct to use human smuggling and human trafficking interchangeably. Migrant smuggling is a contract which asylum seekers agree to; they are not forced into being smuggled. The government focus on using the word human trafficking, and terms related to it, misrepresents the acts of human smugglers and also delegitimize the claims of asylum seekers who arrive by boat.

There are several threats which can be identified in these extracts. One threat is to the integrity of the immigration system. This presented migrant smugglers as individuals who do not hold respect for Canada's refugee system and taking advantage of it. This is related to the theme of a fair system because asylum seekers are once again being portrayed as cheating the immigration system (Schech, 2010). With this depiction, the Canadian government presents Canada's system as being vulnerable and in need of changes.

Another threat mentioned in the discourse is to Canada's borders. This relates to the idea of Canada's sovereignty being under threat. Similar findings have been found in previous 
literature such as in Australia. By presenting Canada's sovereignty or borders as threatened, the government depicts Canada as once again being vulnerable and possibly losing control over who is admitted into Canada (McKenzie \& Hasmath, 2013).

These threats are justified by discussing recent experiences Canada had with asylum seekers; for example:

The illegal arrival of the vessel MV Sun Sea came less than one year after the illegal arrival of the Ocean Lady, which as I mentioned is here behind us. The fact that these two vessels reached our shores in less than 12 months clearly demonstrates that human smuggling networks are targeting Canada (Ministry of Public Safety, 2010)

The fact that two human smuggling vessels reached Canada in recent years is proof of the reach and capability of these human smuggling organizations. It is clear that human smugglers are targeting Canada (Ministry of Citizenship and Immigration, 2012d)

By referring to the recent events of boat arrivals, it creates a feeling of the threat being real or very close to home. The government accomplishes this by using a narrative which refers to recent experiences of boat arrivals and emphasizing how the MV Sun Sea and Ocean Lady arrived to Canada within a very short period of one another. By highlighting these events and the time period, the government attempts to justify or bring attention to the idea of smuggling networks targeting Canada. This is overemphasized because it is only based on two events. The issue of boat arrivals is not an everyday problem for Canada. Therefore, this type of discourse portrays Canada as a country which is constantly being targeted and threatened, when actually it is not.

\section{$\underline{\text { A Fair System }}$}

Another common result was the way in which Canadian political discourse on asylum seekers continuously emphasized the existence of a fair immigration system in Canada. The following excerpt is an example of the discourse used to describe Canada's fair system: 
Canada has an internationally recognized fair system for providing refuge for those

fleeing persecution in their home country (Ministry of Public Safety, 2012c).

This quote suggests to the public that the immigration system is just, impartial and reasonable in regards to asylum seekers. It also infers that the process in which asylum seekers can seek asylum provides equal opportunity to all those who are seeking asylum. However, based on what was discussed in the economic impact section, what the government says does not always reflect the immigration and refugees system correctly. Specific groups of people, like those from Europe, are viewed as 'bogus' and their asylum claims are a waste of taxpayer money. This type of discourse does not represent a fair and impartial system.

Another type of discourse which is used to emphasize Canada's fair system highlights who is accepted into Canada's fair system. The following are quotes illustrate this point:

Our message is clear: Canada opens its doors to those who work hard and play by the rules (Ministry of Public Safety, 2011a).

By re-introducing this legislation we are sending a clear message that our doors are open to those who play by the rules - including all legitimate refugees (Ministry of Public Safety, 2011c).

These two quotes were based on individuals who arrived by boat. A key term used in the above passages was "the rules." The focus on the rules can be interpreted as those who are arriving by boat are not respecting Canada's rules. The discourse implies that those who respect the rules would have done what "real refugees" do by waiting in camps and then being resettled. If they were economic immigrants, they would have applied as skilled workers and then been admitted into Canada based on their application and from there become permanent residents.

Political discourse also simplifies that asylum seekers who arrive by boat are not legitimate refugees and are not fair because they have not followed the procedures Canada has 
designed for those seeking asylum, which was discussed in the introduction section of this paper. However, individuals who arrive at a port of entry and submit an asylum claim there are legitimate according to IRPA (S.C, 2011, s.7). This relates to what was discussed in the literature review. The Australian government has depicted its refugee procedures as being fair because they allow an equal opportunity for those who are seeking asylum to complete an application offshore. However, asylum seekers as not being fair because they are skipping over this process and arriving to Australia in boats (Every \& Augoustinos, 2008). Also, by using this type of discourse it suggests that those who arrive by boat have the ability to follow the rules but choose not to, which is related to the discourse used in Australia (Every \& Augoustinos, 2008).

The queue and queue jumping is also mentioned repeatedly when discussing asylum seekers in Canada's political discourse. The following quotes are examples of this:

Our doors are open to immigrants to Canada who follow the rules and wait in line, but we have no tolerance for those who cheat the system to jump the queue (Ministry of Public Safety, 2012f).

We know that jumping the immigration queue is fundamentally unfair to those who follow the rules and wait their turn to come to Canada (Ministry of Public Safety, 2010).

The bottom line is this. As the Prime Minister recently stated, Canada welcomes and will continue to welcome those who wait their turn to come to Canada in search of a better life (Ministry of Public Safety, 2010).

Queue jumping was a phrase which was found to be very common among previous literature written on this topic. Queue jumpers refer to those who have not waited in camps to be resettled and have reached their destination by boat without approval (McKenzie \& Hasmath, 2009). The political discourse in Canada has depicted asylum seekers who arrive by boat as people who have cheated the fair system and have broken Canada's rules. By using this type of narrative, asylum seekers who arrive by boat and are deemed as not deserving of Canada's protection. The 
depiction of Canada's asylum system as fair and asylum seekers as queue jumpers is a

concurrent theme in Canadian political discourse and in other countries as well.

\section{CHAPTER 6: RESULTS PART II - IMPACT OF POLITICAL DISCOURSE ON CANADA'S ASYLUM SYSTEM}

$\underline{\text { Justification for New Legislation }}$

The following passages are examples of the political discourse which was used to justify the implementation of new legislation such as Bill C-11 and Bill C-31:

As such, we call on all members of Parliament to pass this important legislation without delay and before further boats turn up on Canadian shores (Ministry of Public Safety, 2011a).

This legislation would strengthen Canada's ability to prosecute human smugglers, deter those who would seek to jump the queue, and maintain the integrity and fairness of our immigration system (Ministry of Public Safety, 2011b).

Bill C-31, the Protecting Canada's Immigration System Act, which will be fully implemented later this year, contains strong measures to deter human smugglers. Individuals found guilty of such crimes will face minimum mandatory prison sentences (Ministry of Public Safety, 2012d).

Balanced reforms to Canada's asylum system are being introduced because we must not create a two-tier immigration system: one tier for immigrants who wait in line - often for years - to come to Canada, and another tier for those who use the asylum system, not for protection, but to try to get through the back door into Canada. (Ministry of Immigration and Citizenship, 2010c)

In order to ensure the fairness and integrity of Canada's immigration and refugee systems, and to protect the safety and security of the Canadian public, it is essential that government authorities have the ability to detain, to impose conditions of release, and to remove those who are inadmissible to Canada (Ministry of Citizenship and Immigration Canada, 2012c). 
I would like to commend the RCMP for their ongoing efforts and commitment in their investigation of the smuggling of irregular migrants to Canada aboard the MV Sun Sea," said Minister Toews. "The MV Sun Sea is a vivid example of this ongoing challenge (Ministry of Public Safety, 2012a).

We must have laws and measures in place that will dissuade individuals from coming to Canada by way of an illegal human smuggling venture as opposed to well established means of seeking immigration status or refugee protection in Canada (Ministry of Immigration and Citizenship, 2012e).

The above excerpts depict a desperate need for new laws to be implemented in regards to asylum seekers. A common finding from these excerpts can be the urgency placed on the need for new policies in order to end abuse of the immigration system and to Canada as a whole.

The narratives used in these excerpts by politicians for the public can be explained by the securitization theory. After conveying asylum seekers as an imminent threat, which was accomplished by the negative depiction of asylum seekers in this first chapter of the results, the next step is to gain support from the public to implement tougher legislation. This is completed by placing an emphasis on the two-tier immigration system and ending the abuse of the system with the application of new laws. This provided a solution for the threat to the public; therefore, exceptional measures were implemented (McDonald, 2011).

There is a temporal link between the time that the news releases, backgrounders, statements and speeches were released and when Bill C-11 and Bill C-34 were introduced. This study examined political discourse released between 2009 and 2012. It was found that the majority of the political discourse was released in 2010 and 2012. These are the two years that both Bills were introduced into parliament. For example, out of the 28 articles analyzed: 0 were released in 2009, 9 were released in 2010, 3 were released in 2011 and 16 were released in 2012. This illustrates that the government was drawing the public's attention to the boat arrivals, arrests of migrant smugglers, and the overall abuse of Canada and its immigration system at the 
time that Bill C-11 and Bill C-34 were going through parliament. It can be suggested that the two boat arrivals and the circumstances that surrounded those events was used as political strategy to implement harsher legislation. Although this link is sometimes difficult to demonstrate, a link between government discourse and government policy can be established in this study.

Political discourse has problematized asylum seekers by depicting them in a very negative manner and as a threat. The solution offered to the public to solve the threat of asylum seekers was tougher legislation. These changes were support by the public. For example, opinion polls taken around the time Bill C-31 was going through parliament showed that $50 \%$ of respondents felt that the passengers and crew on the MV Sun Sea and Ocean Lady should have been deported to their country of origin, even if the refugee claims were legitimate and there is was no connection between the migrants and any terrorist organizations (Global Detention Project, 2012). These public opinion polls illustrated that the views of Canadian were hardening in regards to asylum seekers (Global Detention Project, 2012). The Canadian government convinced the general public to agree with the measures stated in both Bills. This was accomplished through the use of political discourse to represent asylum seekers as a security threat to Canada. Even though several problems were found with Bill C-11 and Bill C-31, they were passed in parliament and this was accomplished with the support of the public. This introduced measures such as the designated country of origin policy, mandatory detention of irregular arrivals, and cuts made to refugee healthcare.

\section{Designated Country of Origin (DCO)}

One of the exceptional measures introduced on May 12, 2010, seven months after the Ocean Lady arrived and three months before the MV Sun Sea arrived, was the designated country of origin policy. This policy allows the Minister of Citizenship and Immigration to create a list of 
countries, that do not usually produce refugees because of their respect for human rights and they offer state protection (Bill C-11, 2010, s 2.2.3.1). Refugee claimants from the designated countries of origin list can still apply for asylum in Canada. However, their hearings will be held within 30-45 days after referral of the claim to the Immigration Refugee Board of Canada. Those who do not originate from the designated list have a 60 day time frame. Asylum seekers from the designated country of origin list will not be able to appeal their decisions to the Refugee Appeal Division and cannot apply for a work permit in Canada (Bill C-11, 2010, s 2.2.3.3). Also, those whose refugee claims are unfounded will be sent home through an expedited process (Bill C-11 2010, s 2.2.3.3). The designated country of origin policy increases the chances of mistakes to be made and then the inability for these mistakes to be corrected (Canadian Council for Refugees, 2012).

By accelerating claims, those who are most vulnerable may not have reasonable time to provide evidence to support their claims (Sadrehashem, 2013). The new timelines make it extremely difficult for asylum seekers to find and consult with lawyers and interpreters. Also, claimants may need to collect expert evidence such as medical assessments or psychological reports, which is very difficult to complete under the new timeframe (Sadrehashem, 2013). Asylum seekers who have experienced torture, violence or who have been trafficked may require extra time to complete their claims because of the trauma they have experienced. The designated country of origin accelerated process victimizes the most vulnerable, and does not allow them a chance to appeal their decision (Sadrehashem, 2013).

The implementation of this exceptional measure can be explained by the securitization theory. As discussed earlier, political discourse placed an emphasis on the number of asylum seeker claims which were arriving from the EU and the high rate of them being deemed 
unfounded. This type of discourse persuades the public that there are individuals from countries who are unlikely to experience persecution (McDonald, 2011). If they do claim asylum in Canada, they should not be given the same opportunity as other asylum seekers to process their claim. Another type of discourse which assisted with receiving the public's support for the designated country of origin measure was the emphasis placed on the tax dollars wasted on bogus claims, and the amount of money which could be saved. By depicting asylum seekers in political discourse as a burden to the economy, they are represented as a threat to Canada. This generates support and acceptance for the designated country of origin policy.

According to the securitization theory, the solution to deal with the threat is exceptional measures (Buzan et al, 1998). The designated country of origin policy violates rights because the Minister can designate countries as safe without consulting human rights experts (Canadian Association of Refugee Lawyers, 2012). The criterion used to designate a country as safe is also arbitrary because it does not assure that individual citizens will be protected from persecution; for example, the Jewish or Roma in Hungary (CARL, 2012). The designated country of origin policy creates a two-tier system for refugee determination system claimants are denied asylum based on their nationality (Atak \& Crepeau, 2013).

The designated country of origin policy also specifically violates section seven of the Canadian Charter of Rights and Freedoms (The Constitutional Act, 1982, s.7). This section states that everyone in Canada has the right to life, liberty and security, and the right not to be deprived of these except in accordance with the principles of fundamental justice (The Constitutional Act, 1982, s.7). The designated country of origin policy is problematic because it could potentially deny a fair process for asylum seekers. The accelerated time lines could interfere with asylum seeker's access to lawyers, doctors and translators making their claims 
seem not legitimate. The government has imposed oppressive restrictions on certain groups of asylum seekers, which makes it difficult for them to process their refugee claims and have them approved.

\section{$\underline{\text { Detention }}$}

Bill C-31 permits the Minister of Public Safety the ability to designate certain groups as irregular arrivals (Bill C-31, 2012, s 2.2). If the Minister feels that there are reasonable grounds to believe that individuals were smuggled into the country or if the examination of the group's members cannot be completed in a timely manner then the asylum seekers will be placed in detention (Bill C-31, 2012, s 2.2.). Those who are in these designated groups will endure mandatory imprisonment for up to one year without judicial review. This includes adults and children who are sixteen years old and older (Bill C-31, 2012, s 2.2.3). Also, asylum seekers who have been labelled irregular arrivals will not have the right to apply for permanent residency, travel outside of Canada or sponsor their family for five years. The Minister has the ability to revoke refugee status from irregular arrivals up to the date of citizenship, which would mean deportation for them as well (Bill C-31, 2012, s.2.2.3.4.3).

These tougher detention measures were implemented because the discourse surrounding the matter was based on the prevention of migrant smuggling (Bill C-31, 2012, s 2.2). As described earlier in the results section, the discourse places a strong emphasis on the threat migrant smugglers present. Migrant smugglers as the same as those who participate in human trafficking, which depicts them as being more evil and despicable than they really are. Those who are smuggled are viewed as possible accomplices; therefore, they must be placed in detention as a deferent in order to keep Canadians safe and punish those who are involved with migrant smuggling. As already mentioned, in the case of the MV Sun Sea and the Ocean Lady, 
out of the 568 asylum seekers who arrived, 19 were deported, 6 had their claims rejected and 543 had their refugee claims approved (Perrin, 2012). This demonstrates that the large majority of those who seek asylum are genuine refugees fleeing from persecution. However, political discourse presents those deemed as 'irregular arrivals' as threats to Canada and the only way to prevent them from being a security threat is by placing them in detention. Therefore, the securitization theory applies to this measure.

The mandatory detention of certain groups of irregular arrivals is an exceptional measure because it violates section nine of the Charter, which states that everyone has the right not to be arbitrarily detained or imprisoned (The Constitutional Act, 1982, s 9). This is exactly what is happening to certain groups of asylum seekers. Detention is problematic because it can result in severe psychological problems for asylum seekers. This includes depression, anxiety, self-harm and suicide (Tuckfield, 2014).

The detention of asylum seekers also violates the Refugee Convention (Refugee Convention, 1951, s 31.1). Detention is deemed as a last resort after each case is examined to ensure that individual rights are not being violated (Atak \& Crepeau, 2013). International law also states that the duration of detention should be as short as possible and not go beyond a period that can be justified by the state. In 2008, the Supreme Court of Canada found that people should not be detained arbitrarily and that the review of any detention should take place as soon as possible (Atak \& Crepeau, 2013). Therefore, the mandatory detention policy violates these regulations and goes beyond Canada's own laws (Amnesty, 2012).

\section{$\underline{\text { Health Cuts }}$}

A last exceptional measure which was implemented was the changes made to the Interim Federal Health program for refugees (FC 651, 2014). The IFH program provided medical care, 
diagnostic services and laboratory testing very similar to what provincial health care plans deliver. Furthermore, it allowed access to medication, emergency dental and vision care similar to what social assistance plans provide. These services were given to all different types of refugees, including refugee claimants who make refugee claims after arriving to Canada. In the previous IFH program, refugee claimants would have access to doctors and laboratory and diagnostic testing through the IFH program (FC 651, 2014).

The changes made to the program resulted in lost medication coverage, vision and dental care that was provided through the IFH program for refugees claimants (Bill C-31, s. 2.1.2.1). Also, people from designated countries of origin would not have health coverage (Bill C-31, s. 2.2.4). Health coverage would only be available to these individuals in case of public health concerns and for issues of public security (Barnes, 2013). These changes were implemented because the previous program was presented as a threat to the economy and asylum seekers are deemed as undeserving because they are abusing the system. The political discourse in the economic impact section emphasized that tax dollars were being wasted on health costs and social assistance. This type of discourse depicts asylum seekers as a burden, problem and threat to the Canadian economy. As the securitization theory outlines, if a threat and problem are identified by the government it is always solved by exceptional measures. In this case, it was the major cuts to the IFH program. Providing refugee claimants with healthcare before they have been designated as refugees is also described as an abuse of the system in political discourse. The government depicts asylum seekers as making fake claims of asylum in order to abuse Canada's healthcare system. Asylum seekers are once again presented as a threat and the solution to this problem was cuts to asylum seeker healthcare (Barnes, 2013). 
The cuts made to the IFH program were widely disputed by many groups including the Canadian Doctors for Refugee Care, because this exceptional measure was viewed as a violation of human rights (FC 651, 2014). This is because asylum seekers are suffering greatly from being denied access to medical care. They may be experiencing major physical and mental health complications which should not be ignored. Because of these worries, the Canadian Doctors of Refugee Care went to the Federal Court and fought to have the new changes to the IFH program reversed (FC 651, 2014).

The Federal Court found that the cuts made to refugee health care were cruel and unusual without any justification (FC 651, 2014). This is a violation of section twelve of the Canadian Charter of Human Rights and Freedom, which states that everyone has the right not to be subjected to cruel and unusual treatment or punishment (FC 651, 2014). The government was given four months to change the cuts that were made to the IFH program. This decision is currently being appealed by the federal government (Payton, 2014).

\section{CHAPTER 7: CONCLUSION}

This study found that Canadian political discourse on asylum seekers tends to be very similar to the discourse that has prevailed in Europe, Australia and South Africa. Generally asylum seekers are depicted in a negative manner as threats to safety, breaking the rules of a fair system, abusing the system and draining the economy. Meanwhile, the asylum seeking country portrays itself as very generous and compassionate. This follows the ideas behind the securitization theory.

Asylum seekers and migrant smugglers were depicted as a danger to Canada and urgency was placed on exceptional measures to be implemented. The political discourse created a security threat over the issue of asylum seekers and proposed a solution to create Bill C-11 and 
Bill C-31 to deter the threat. It can be proposed that the public was persuaded through the discourse used, and came to support the implementation of tougher legislation against asylum seekers. This resulted in harsh measures such as the designated country of origin policy, detention of irregular arrivals, and massive cuts to the IFH program.

This study suggests the ability of language to be used as a weapon to persuade the public to introduce exceptional measures. With the implementation of Bill C-31 and Bill C-11, Canada is moving towards harsher policies like those in Australia and in Europe. Political discourse tends to focus on the threat asylum seekers bring to Canada. Perhaps a focus should be placed on the difficult experiences of asylum seekers and the support they could use. The exceptional measures discussed in this paper are a violation of basic human rights and do not reflect the humanitarian objectives of the Immigration and Refugee Protection Act. 
APPENDIX

$\underline{\text { Data Collection Tool }}$

\begin{tabular}{|l|l|l|l|l|l|l|l|l|l|l|l|}
\hline Ministry & Type & Date & Title/Heading & Who & $\begin{array}{l}\text { Us vs } \\
\text { Them }\end{array}$ & $\begin{array}{l}\text { Emphasis } \\
\text { on } \\
\text { Generosity }\end{array}$ & $\begin{array}{l}\text { Fair } \\
\text { System }\end{array}$ & $\begin{array}{l}\text { Economic } \\
\text { Impact }\end{array}$ & $\begin{array}{l}\text { Negative } \\
\text { Labels }\end{array}$ & $\begin{array}{l}\text { Threat } \\
\text { Bill C- } \\
\text { 31/Bill } \\
\text { C11 }\end{array}$ & \begin{tabular}{l} 
Other \\
\hline
\end{tabular} \\
& & & & & & & & & & & \\
\end{tabular}




\section{BIBLIOGRAPHY}

Amnesty International Canada. (2012). Unbalanced reforms: Recommendations with respect to Bill C-31. Retrieved from the Amnesty International Canada website:

http://www.amnesty.ca/sites/default/files/ai_brief_bill_c_31_to_parliamentary_committe e_0.pdf

Atak, I. \& Crepeau, F. (2013). The securitization of asylum and human rights in Canada and in the European Union. In S. Juss (Ed) \& C. Harvey (Ed), Contemporary Issues in Refugee Law. (pg 227-257). Cheltenham, UK: Edward Elgar Pub.

Babacan, A. (2007). The criminalisation of asylum seekers in Australia. School of Accounting \& Law 2(1) 44-49.

Barnes, S. (2013). The real cost of cutting the Interim Federal Health Program. Retrieved from the Wellesley Institute website: http://www.wellesleyinstitute.com/wpcontent/uploads/2013/10/Actual-Health-Impacts-of-IFHP.pdf

Bauder, H. (2013) Why We Should Use the Term Illegalized Immigrant. RCIS Research Brief 2013 No. 1

Bradimore, A. and Bauder, H. (2011) Mystery Ships and Risky Boat People: Tamil Refugee Migration in the Newsprint Media. Canadian Journal of Communication 36: 367-661.

Buzan, B., Weaver, O. \& Wilde, J. (1998). Security: A New Framework for Analysis. Boulder, Colorado: Lynne Rienner Publishers.

Seidman-Zager, J. (2010). The securitization of asylum: Protecting UK residents. Working Paper Series 2010 No. 57

Bill C-11: An Act to Amend the Immigration and Refugee Protection Act and the Federal Courts Act (Balanced Refugee Reform Act). $1^{\text {st }}$ Reading May 12, 2010, 40 ${ }^{\text {th }}$ Parliament, $3^{\text {rd }}$ session. Retrieved from the Parliament of Canada website: http://www.parl.gc.ca/Content/LOP/LegislativeSummaries/40/3/c11-e.pdf

Bill C-31: An Act to Amend the Immigration and Refugee Protection Act and the Federal Courts Act, Balanced Refugee Reform Act, the Marine Transportation Security Act. And the Department of Citizenship and Immigration Act. $1^{\text {st }}$ reading Feb. 16, 2012, $41^{\text {st }}$

Parliament, $1^{\text {st }}$ session. Retrieved from the Parliament of Canada website: http://www.parl.gc.ca/Content/Lop/LegislativeSummaries/41/1/c31-e.pdf

Busch, C., De Maret, P., Flynn, T., Kellum, R., Le, Sheri., Meyers, B., Sanders, M., White, R. \& Palmquist, M. (2012). Content Analysis. Writing @CSU. Retrieved September 9, 2014, from: http://writing.colostate.edu/guides/guide.cfm?guideid=61.

Canadian Association of Refugee Lawyers (2012). Designated Country Of Origin Scheme Is Arbitrary, Unfair, And Unconstitutional. Retrieved from the Canadian Association of 
Refugee Lawyers website: http://www.carl-acaadr.ca/our-work/issues/DCO\#Press Release DCO

Canadian Council for Refugees (2011). Bill C4- Comments on a bill that punishes refugees. Retrieved from the Canadian Council for Refugees website: https://ccrweb.ca/en/c4

Canadian Council for Refugees (2012) Canada Rolls Back Refugee Protection: Bill C-31 receives Royal Assent. Retrieved from the Canadian Council for Refugees Website: https://ccrweb.ca/en/bulletin/12/06/29

Canadian Tamil Congress (2010). The Case of Ocean Lady's 76 Tamil Refugees. Retrieved from the Canadian Tamil Congress website: http://www.docstoc.com/docs/72996933/TheCase-of-Ocean-Ladys-76-Tamil-Refugees

Canadian Tamil Congress (2011). Rights advocates decry detention of refugee claimants from MV Sun Sea. Retrieved from the Canadian Tamil Congress website: http://www.canadiantamilcongress.ca/Press_Releases/AI\%20CCR\%20ICLMG\%20CTC \%20Press\%20Release\%20Feb\%2010\%202011.pdf

Chase, S. (2013, February 22). New fast-track rules see big drop in refugee asylum claims. The Globe and Mail. Retrieved from: http://www.theglobeandmail.com/news/politics/newfast-track-rules-see-big-drop-in-refugee-asylum-claims/article8961268/

CIC (2014, June 30). Our Mandate. Retrieved from: http://www.cic.gc.ca/english/department/mission.asp

Convention Relating to the Status of Refugees (adopted 28 July 1951, entered into force 22 April 1954) 189 UNTS 150 (Refugee Convention)

Conway, A. (2011). Examining the "Illegitimate" Refugee Label: A case study of Roma Refugee Claimants in Canada, 2008-2009. Ph.D. Thesis, Carleton University, Ottawa. Retrieved from: http://search.proquest.com.ezproxy.lib.ryerson.ca/pqdtft/docview/1000517934/91005B63 8FBA4158PQ/24?accountid=13631\#

Every, D. \& Augoustinos, M. (2008). Construction of Australia in pro-and anti-asylum seeker political discourse. Nations and Nationalism 14(3) 562-580.

Fitzgerald, C. (2013). Prejudice and empathy in political discourse: A look into language used by politicians in the asylum seeker debate. Macquarie Matrix 3(1) 1-28.

Global Detention Project (2012). Immigration detention in Canada: A global detention project special report. Retrieved from the Global Detention Project website: http://www.globaldetentionproject.org/fileadmin/publications/Canada_special_report_20 12_2.pdf

Goodman, S. (2007). Justifying harsh treatment of asylum seekers through the support of social cohesion. Annual Review of Critical Psychology 6(1) 110-124. 
Huberman, M. \& Miler, M. (1994) Qualitative data analysis. Thousand Oaks: Sage (Selected diagrams).

Huysmans, J. (2000). The European Union and the securitization of Europe. Journal of Common Market Studies 38(5) 751-771.

Ibrahim, M. (2005). The securitization of migration: A racial discourse. International Migration 43(5) 163-187.

Immigration and Refugee Protection Act, SC 2001, c 27, <http://canlii.ca/t/529s2> retrieved on 2014-08-22

Leonard, S. (2007, September 12-15). The 'Securitization' of Asylum and Migration in the European Union: Beyond the Copenhagen School's Framework. Paper presented at SGIR Sixth Pan-European International Relations Conference, Turin, Italy. Doi: http://www.eisa-net.org/be-bruga/eisa/files/events/turin/Leonardsgir_conference_paper_final_sleonard.pdf

McDonald, M. (2011). Deliberation and resecuritization: Australia, asylum-seekers and the normative limits of the Copenhagen School. Australian Journal of Political Science 46(2) 281-295.

Mayring, P. (2000). Qualitative Content Analysis. Forum, Qualitative, Sozialforschung 2(1) 110.

McKenzie, J. \& Hasmath, R. (2013). Deterring the 'boat people': Explaining the Australian government's People Swap response to asylum seekers. Australian Journal of Political Science 48(4) 417-430.

Nakache, D. (2011). The human and financial cost of detention of asylum seekers in Canada. Retrieved from the UNHCR website: http://www.unhcr.ca/resources/documents/RPT2011-12-detention_assylum_seekers-e.pdf

Neuman, W.L. (2006). Basics of social research: Qualitative and quantitative approaches. Boston, MA: Pearson

No One Is Illegal. (2010). Myths and realities about 490 Tamil refugees on MV Sun Sea. Retrieved from the NOII website: https://noii-van.resist.ca/?p=2167

Payton, L. (2014, July 4). Federal government to appeal ruling reversing 'cruel' cuts to refugee health. $C B C N E W S$. Retrieved from: http://www.cbc.ca/news/politics/federal-governmentto-appeal-ruling-reversing-cruel-cuts-to-refugee-health-1.2696311

Perrin, B. (2011) Migrant Smuggling: Canada's Response to a Global Criminal Enterprise: With an Assessment of the Preventing Human Smugglers from Abusing Canada's Immigration System Act. Macdonald-Laurier Institute, 201 
Poynter, B. (2012, November 29). Canada accused of treating Tamil asylum seekers like prisoners. The Guardian. Retrieved from: http://www.theguardian.com/world/2012/nov/29/canada-accused-tamil-asylum-prisoners

Rosenkranz, E. (2013). "Those people" - Political construction of refugees and asylum seekers in South Africa. Development Studies 30(1) 1-79.

Rowe, E. \& O'Brien, E. (2013). Constructions of asylum seekers and refugees in Australian political discourse. Crime Justice and Social Democracy 2(1) 173-181.

R. v. Canadian Doctors for Refugee Care, The Canadian Association of Refugee Lawyers, Daniel Garcia Rodriques, Hanif Ayubi and Justice for Children and Youth. Federal Court. 2014. Retrieved from the Department of Justice website: http://cas-ncr-nter03.cassatj.gc.ca/rss/T-356

13\%20Cdn\%20Doctors\%20v\%20AGC\%20Judgment\%20and\%20Reasons.pdf

Sadrehashem, L. (2013). Vulnerable Claimants and the new refugee determination process. Retrieved from the Refugee Lawyers Groups website: http://refugeelawyers.net/2d_Sadrehashemi.pdf

Samaranayake, G. (2007). Political terrorism of the Liberation Tigers of Tamil Eelam (LTTE) in Sri Lanka. South Asia: Journal of South Asian Studies 30(1) 171-183.

Schech, S. (2012). Seeing Like a Region: Parliamentary Discourses on Asylum Seekers and Refugees in Scotland and South Australia. Population, Space \& Place 18 (1) 58-73.

Shakir, Uzma. (2010, August 16). Canada's treatment of the Tamil refugees is a defining moment. Rabble. Retrieved from: http://rabble.ca/news/2010/08/canada\%E2\%80\%99streatment-tamil-refugees-defining-moment

Steele, L. (2013). 'Bogus Claims': A Discursive Analysis of the Portrayal of Hungarian Roma Asylum Seekers in Canada. Master's Thesis, Central European University. Retrieved from: file:///C:/Users/user/Downloads/steele_lisa.pdf

Taureck, R. (2006). Securitization theory and securitization studies. Journal of International Relations and Development 9(1) 53-61.

The Constitution Act, 1982, Schedule B to the Canada Act 1982 (UK), 1982, c 11, $<$ http://canlii.ca/t/ldsx > retrieved on 2014-08-23

Tuckfield, H. (2014, February 18). Australia's Troubling Asylum Seeker Policy. The Diplomat. Retrieved from: http://thediplomat.com/2014/02/australias-troubling-asylum-seekerpolicy/

United Nations Higher Commission for Refugees (2011). The human and financial cost of detention of asylum-seekers in Canada. Retrieved from the UNHCR website: http://www.unhcr.ca/resources/documents/RPT-2011-12-detention_assylum_seekerse.pdf 
Van Dijk, D. (2006, September 21-23). Is the EU policy on illegal immigrant securitized? Yes of Course! A study into the dynamics of institutionalized securitization. Paper presented at the $3^{\text {rd }}$-Pan European Conference on EU politics, Istanbul doi: http://www.jhubc.it/ecpristanbul/virtualpaperroom/054.pdf

\section{$\underline{\text { Political Discourse Articles }}$}

Kenney, J. (2010, March). - Remarks by the Honourable Jason Kenney, P.C., M.P. Minister of Citizenship, Immigration and Multiculturalism an balanced refugee reform. Presented at Ottawa, ON.

Kenney, J. (2012, February). Bill C-31, Protecting Canada's Immigration System Act. Presented at the House of Commons, Ottawa, ON.

Ministry Citizenship and Immigration. (2010a). The Balanced Refugee Reform Act moves closer to becoming law (News Release). Retrieved from: http://news.gc.ca/web/articleen.do?m=/index\&nid=540079

Ministry Citizenship and Immigration. (2010). Governments of Canada and Australia working to combat human smuggling. (News Release). Retrieved from: http://news.gc.ca/web/article-en.do?m=/index\&nid=560859

Ministry Citizenship and Immigration. (2010b). Ministers Toews and Kenney discuss Preventing Human Smugglers from Abusing Canada's Immigration System Act (News Release). Retrieved from: http://news.gc.ca/web/article-en.do?m=/index\&nid=568059

Ministry Citizenship and Immigration. (2010c). Backgrounder - Challenges faced by Canada's asylum system (News Release). Retrieved from: http://www.cic.gc.ca/english/DEPARTMENT/media/backgrounders/2010/2010-0330a.asp

Ministry Citizenship and Immigration. (2010e). Backgrounders - Bill C-11: The Balanced Refugee Reform Act (News Release). Retrieved from http://www.cic.gc.ca/english/department/media/backgrounders/2010/2010-03-30.asp

Ministry Citizenship and Immigration. (2010d). Backgrounder - Proposed reforms to Canada's asylum system (News Release). Retrieved from http://www.cic.gc.ca/english/department/media/backgrounders/2010/2010-06-29.asp

Ministry Citizenship and Immigration. (2010). Government of Canada introduces the Preventing Trafficking, Abuse and Exploitation of Vulnerable Immigrants Act (News Release). Retrieved from: http://news.gc.ca/web/article-en.do?m=/index\&nid=574699

Ministry Citizenship and Immigration. (2012a). Harper Government Introduces the Protecting Canada's Immigration System Act (News Release). Retrieved from: http://news.gc.ca/web/article-en.do?nid=657129 
Ministry Citizenship and Immigration. (2012b). Making Canada's Asylum System Faster and Fairer - New Asylum System Comes into Force December 15, 2012 (News Release). Retrieved from: http://news.gc.ca/web/article-en.do?nid=712349

Ministry of Public Safety (2011a). Minister Toews updates Canadians on efforts to prevent human smugglers from abusing Canada's immigration system (News Release). Retrieved from: http://www.publicsafety.gc.ca/cnt/nws/nws-rlss/2011/20110119-1-eng.aspx

Ministry of Public Safety (2011b). Public Safety Minister Toews and MP Joy Smith discuss the Preventing Human Smugglers from Abusing Canada's Immigration System Act with Winnipeg community leaders (News Release). Retrieved from: http://www.publicsafety.gc.ca/cnt/nws/nws-rlss/2011/20110124-eng.aspx

Ministry of Public Safety (2011c). Government of Canada takes action to prevent human smugglers from abusing Canada's immigration system (News Release). Retrieved from: http://www.publicsafety.gc.ca/cnt/nws/nws-rlss/2011/20110616-eng.aspx

Ministry Citizenship and Immigration. (2012c). Backgrounder — Protecting our Streets and Communities from Criminal and National Security Threats (News Release). Retrieved from http://www.cic.gc.ca/english/department/media/backgrounders/2012/2012-0629i.asp

Ministry Citizenship and Immigration. (2012d). Backgrounder - Overview: Ending the Abuse of Canada's Immigration System by Human Smugglers (News Release). Retrieved from http://www.cic.gc.ca/english/DEPARTMENT/media/backgrounders/2012/2012-0629k.asp

Ministry Citizenship and Immigration. (2012e). Backgrounder - Cracking down on Human Smugglers who Abuse Canada's Immigration System (News Release). Retrieved from http://www.cic.gc.ca/english/department/media/backgrounders/2012/2012-06-29j.asp

Ministry Citizenship and Immigration. (2012). Backgrounder — Designating Human Smuggling Events (News Release). Retrieved from http://www.cic.gc.ca/english/department/media/backgrounders/2012/2012-06-29f.asp

Ministry Citizenship and Immigration. (2012). Backgrounder - Overview: Ending the Abuse of Canada's Immigration System by Human Smugglers (News Release). Retrieved from http://www.cic.gc.ca/english/department/media/backgrounders/2012/2012-06-29i.asp

Ministry Citizenship and Immigration. (2012). Backgrounder - Cracking down on Human Smugglers who Abuse Canada's Immigration System (News Release). Retrieved from http://www.cic.gc.ca/english/DEPARTMENT/media/backgrounders/2012/2012-0216b.asp

Ministry Citizenship and Immigration. (2012f). Backgrounder - Protecting our Streets and Communities from Criminal and National Security Threats (News Release). Retrieved from http://www.cic.gc.ca/english/DEPARTMENT/media/backgrounders/2012/2012-0629k.asp 
Ministry of Public Safety (2012). Public Safety Minister Vic Toews and Citizenship, Immigration and Multiculturalism Minister Jason Kenney make a statement on the laying of human smuggling charges (News Release). Retrieved from:

http://www.publicsafety.gc.ca/cnt/nws/nws-rlss/2012/20120307-1-eng.aspx

Ministry of Public Safety (2012). Statement on new arrest in connection with the MV Sun Sea (News Release). Retrieved from: http://www.publicsafety.gc.ca/cnt/nws/nwsrlss/2012/20120606-1-eng.aspx

Ministry of Public Safety (2012). Ministers Toews and Kenney commend Canada Border Services for preventing human smuggling (News Release). Retrieved from: http://www.publicsafety.gc.ca/cnt/nws/nws-rlss/2012/20120706-1-eng.aspx

Ministry of Public Safety (2012d). Ministers Toews and Kenney commend law enforcement for arrests in alleged human smuggling/trafficking ring (News Release). Retrieved from: http://www.publicsafety.gc.ca/cnt/nws/nws-rlss/2012/20120906-eng.aspx

Ministry of Public Safety (2012e). Minister of Public Safety makes first designation of irregular arrival under Protecting Canada's Immigration System Act (News Release). Retrieved from: http://www.publicsafety.gc.ca/cnt/nws/nws-rlss/2012/20121205-eng.aspx

Ministry of Public Safety (2012f). Harper Government takes action against human smuggling (News Release). Retrieved from: http://www.publicsafety.gc.ca/cnt/nws/nwsrlss/2012/20121205-1-eng.aspx

Toews, V. (2010, October). Human Smuggling and the Abuse of Canada's Refugee System. Speech presented at the Marine Base, Unit 3, Vancouver, BC. 